\title{
TRAINING FINANCIAL GOVERNANCE FOR SMALL BUSINESS GR OUPS IN THE KARONDORAN VILLAGE AND EASTERN LANGOWAN DISTRICT
}

\author{
Johny Manaroinsong 1), Mareyke Greety Velma Sumual ${ }^{2}$ ), Lennij Henij Suoth ${ }^{3}$ ) \\ Fakultas Ekonomi, Universitas Negeri Manado 1),2),3),4) \\ email: manaroinsongjohny@gmail.com ${ }^{1)}$
}

\begin{abstract}
In phenomenological that capital improvements micro and small businesses that are not necessarily able to manage venture capital, although the amount of lending by the government continue to grow. The most important factor faced by micro businesses related to the ability to create a business plan, do the bookkeeping and calculate profit and loss through the preparation of financial statements of small businesses. This ability can only be done if the micro and small entrepreneurs have obtained special assistance, such as training on the highly strategic with regard to financial governance. Framework for problem solving is done with the following process: 1) know the initial conditions of financial management; 2) A touch of science and technology through training in financial management systems. By using the proper training on ways financial management system that is efficient and effective, it is expected there will be changes in behavior; 3) The expected result, after the implementation of the training. This activity can be tested through the stages at least one month after the training. The results were obtained: 1) Model and small business bookkeeping cycle and simple calculations of profit and loss, are important materials which not only known, but should be understood in the transaction of business activities in order to be recorded correctly according to the actual situation; 2) training was very positive response bec ause it is closely related to their daily activities, so itfelt a primary requirement. 3) small businesses in the Karondoran village and Eastern Langowan District has managed to gain knowledge of the Model and the cycle of small business bookkeeping as well as feasibility studies (businness Plan) is simple. Therefore, training and habituation of micro and small entrepreneurs continuously followed by appropriate change-change business development, will be very much needed.
\end{abstract}

Keywords: Model and the cycle of small business bookkeeping, business plan 


\section{PENDAHULUAN}

Kemiskinan merupakan masalah pembangunan kesejahteraan sosial yang berkaitan dengan berbagai bidang pembangunan lainnya yang ditandai oleh pengangguran, keterbelakangan, dan ketidakberdayaan. Oleh karena itu, kemiskinan terutama yang diderita oleh kaum miskin merupakan masalah pokok nasional yang penanggulanggannya tidak dapat ditunda lagi dan harus menjadi prioritas utama dalam pelaksanaan pembangunan kesejahteraan sosial. Penanganan kaum miskin tidaklah mudah, karena kaum miskin telah mengalami masalah kemiskinan yang berlangsung lama. Kaum miskin mengalami keterbatasan dalam hal pendidikan, keterampilan, sarana usaha serta modal usaha. Tawaran kredit Usaha Mikro Kecil dan Menengah (UMKM) dari pengusaha dan perbankan sulit diakses oleh kaum miskin, karena keterbatasan kemampuan dan asset yang dimiliki. Pemerintah dalam hal ini dinas sosial berusaha menemukan pola yang efektif agar kaum miskin dapat memperoleh akses modal usaha tanpa agunan dengan tetapmendorong tanggungjawab bersama melalui pola terpadu Kelompok Usaha Kecil (KUK) dan Lembaga Keuangan Mikro (LKM). Kecamatan Langowan Timur terdiri dari 9 Desa. Peranan masing-masing desa dalam menciptakan nilai tambah pendapatan bruto sangat bervariasi. Desa Krondoran Kecamatan Langowan Timur Kabupaten Minahasa, mempunyai peran antara 2-5 persen dalam kontribusinya terhadap nilai tambah pendapatan bruto di Kecamatan Langowan. Kondisi inilah yang memungkinkan untuk ditingkatkan seiring dengan rendahnya kontribusi kelompok usaha kecil ini dalam meningkatkan usahanya. Masalah yang hendak diselesaikan dalam pengabdian pada masyarakat ini adalah bagaimana memberdayakan masyarakat miskin di pedesaan melalui usaha ekonomi produktif, diantaranya pemberdayaan masyarakat dalam penanggulangan kemiskinan melalui bantun teknis pengelolaan modal usaha yang dipinjamkan.

Kelompok usaha kecil berbentuk usaha mikro dan kecil terus menerus bekembang dan bertahan dalam perkonomian global yang sedang menurun, stabil maupun saat perekonomian terus meningkat. Negara berkembang seperti Indonesia memiliki masalah dalam kemiskinan yang harus ditangani dengan optimal, usaha mikro dan kecil merupakan salah satu sektor yang menurunkan tingkat kemiskinan di Indonesia. Ismawan, (2013), mengatakan bahwa dalam menanggulangi masalah kemiskinan di Indonesia, pengembangan usaha mikro merupakan sebuah solusi yang baik bila dapat dioptimumkan karena di Indonesia lapisan pengusaha mikro dan kecil sebesar 98 persen dari seluruh total unit usaha. Sektor usaha mikro, kecil dan menengah di Indonesia sangat potensial dikembangkan. Menurut Kementrian Koperasi dan UKM, (2013), Sektor UMKM yang didalamnya terdapat usaha kecil dan usaha mikro terbukti memberikan kontribusi 57,12 persen terhadap Produk Domestik Bruto (PDB), bahkan sektor ini telah menyerap 101,72 juta orang tenaga kerja atau 97,3 persen dari total tenaga kerja Indonesia

Permasalahan usaha mikro salah satunya adalah kurangnya permodalan. Hal ini didukung oleh analisis dari Ismawan yang menyatakan bahwa kesulitan usaha mikro dan kecil yang utama adalam permodalan, dengan persentasi antara 36 persen hingga 50 persen dibanding dengan lima jenis kesulitan lain seperti pengadaan bahan baku, pemasaran, teknik produksi dan manajemen serta persaingan. Pernyataan ismawan didukung oleh data dari Badan Pusat Statistik, 2013, dalam sensus UMKM yang menyatakan bahwa kendala permodalaman KUMKM yang didalamnya terdapat usaha kecil dan mikro adalah sebesar 21,62 persen. Dalam mendukung usaha mikro dan kecil untuk terus berkembang maka berbagai pihak seperti pemerintah dan pihak-pihak yang dapat membantu harus memberikan pemecahan masalah khususnya dari kebutuhan modal. Semua upaya dari berbagai pihak untuk memecahkan permasalahan dan kendala usaha mikro dan kecil akan berdampak pada perkembangan usaha mikro dan kecil sekaligus untuk membuat pelaku usaha mempersiapkan diri menghadapi mayarakat 
ekonomi ASEAN pada tahun 2015 sebagai bentuk integrasi ekonomi ASEAN. Menurut Rachmad Subiyanto $(2013 ; 1)$ bahwa keterbatasan modal bagi pelaku usaha mikro dan kecil kelompok menjadi salah satu penyebab pertumbuhan usaha sektor ini terkendala pada keterbatasan modal, kendati jumlah penyaluran kredit terus bertumbuh. Peningkatan permodalan pelaku usaha mikro dan kecil itu tidak bisa serta merta mampu mengelola modal usaha. Hal ini disebabkan oleh banyak faktor, dimana faktor terpenting adalah berkaitan dengan kemampuan membuat bisnis plan, melakukan pembukuan, dan menghitung laba rugi melalui penyusunan laporan keuangan usaha kecil. Kemampuan ini hanya bisa dilakukan apabila pengusaha miro dan kecil memperoleh perlakuan khusus, seperti pelatihan tentang hal itu.

Atas dasar itu tujuan kegiatan pengabdian ini adalah: 1) Menumbuhkan semangat berwirausaha bagi masyarakat miskin melalui pembentukan kelompok usaha bersama; 2) Memberdayakan potensi masyarakat miskin dalam meningkatkan pendapatan keluarga melalui peningkatan usaha ekonomi produktif; 3) Setelah pelaksanaan pembinaan melalui ceramah, diskusi, simulasi dan praktik, diharapkan, peserta : a) Memahami tentang Tata kelola keuangan bagi kelompok usaha kecil di Desa Karondoran Kecamatan Langowan Timur, b) Mengetahui manajemen usaha dan keuangan usaha, c) Terampil menyusun pembukuan Usaha Kecil, d) Terampil menyusun dan menghitung laba rugi usahakecil, dan e) Terampil menyusun kelayakan usaha untuk permintan kredit UMK.

Pada hakekatnya kemiskinan menurut Moeljarto (1994) tidak hanya persoalan kesejahteraan tetapi ada enam alasan yang dapat dijadikan sebagai dasar orang dikatakan miskin, yaitu: (1) kemiskinan adalah masalah kerentanan; (2) kemiskinan berarti tertutupnya akses kepada berbagai peluang bagi mereka untuk berpartisipasi dalam proses produksi, atau terperangkap pada hubungan produksi yang ekspotatif dengan imbalan yang rendah; (3) kemiskinan adalah masalah ketidakpercayaan, perasaan impotensi emosional dan sosial atas keputusan yang dilakukan elit birokrasi dalam berbagai tingkat; (4) kemisknan berarti juga menghabiskan semua atau sebagian besar penghasilan untuk konsumsi pangan dalam kuantitas dan kualitas yang terbatas sehingga konsumsi gizi rendah yang berakibat pada produksi yang rendah; (5) kemiskinan ditandai dengan rendahnya rasio, ketergantungan karena besarnya tanggungan keluarga yang berakibat rendahnya konsumsi sehingga berpengaruh pada kecerdasan; dan (6) kemiskinan juga terefleksi pada budaya yang diwariskan dari satu generasi ke generasi lain.

Alfian, Tan dan Soemardjan (1980) mengatakan ada dua kategori pengukuran tingkat kemiskinan yaitu kemiskinan absolut dan kemiskinan relatif. Kemiskinan absout merupakan suatu kondisi dimana tingkat pendapatan seseorang tidak cukup untuk memenuhi kebutuhan pokok seperti pangan, sandang, papan, kesehatan dan pendidikan. Sedangkan kemiskinan relatif adalah penghitungan kemiskinan berdasarkan proporsi distribusi pendapatan dalam suatu daerah. Kemiskinan ini dikatakan relatif karena lebih berkaitan dengan distribusi pendapatan lapisan social. Dengan demikian, membicarakan kemiskinan merupakan suatu persoalan yang kompleks dan perlu didekati dari berbagai aspek, namun untuk memahami kemiskinan yang obyektif ada indikator yang dapat menjadi patokan pengukuran. Bank Dunia menetapkan garis batas kemiskinan \$US 50 per kapita tahun ata sama dengan Rp.650.000/per orang/tahun.

Pengembangan Usaha Ekonomi Produktif (UEP) dan Usaha Kesejahteraan Sosial (UKS) melalui Kelompok Usaha Kecil (KUK) bagi kaum miskin merupakan salah satu program yang dikembangkan pemerintah melalui dinas sosial. Pengembangan Lembaga Keuangan Mikro KUK Sejahtera yang didirikan di setiap desa miskinuntuk memfasilitasi modal usaha bagi KUK-KUK kaum miskin. Melalui KUBE diharapkan masyarakat miskin dapat mengembangkan potensinya sehingga dapat meningkatkan taraf hidup keluarga.

\section{METODE}


Kerangka pemecahan masalah dilakukan dengan proses sebagai berikut: 1) Kondisi awal. Sebelum pelaksanaan kegiatan pelatihan pengelola keuangan, kondisi awalnya keadaan usaha kecil yang tidak menerapkan sistem pengelolaan keuangan yang belum transparan dan akuntabel, disebabkan mereka belum tau dan tidak biasa melakukannya. Kodisi tersebut menyebabkan mereka tidak bisa menentukan dengan tepat sistem pengelolaan keuangan yang belum efisien dan efektif. 2) Sentuhan ipteks melalui pelatihan. Metode pemecahan terhadap masalah yang dihadapi sistem pengelolaan keuangan yang belum efisien dan efektif ini, adalah melalui proses pelatihan. Dengan menggunakan metode pelatihan yang tepat tentang cara-cara sistem pengelolaan keuangan yang efisien dan efektif, maka diharapkan akan terjadi perubahan perilaku. Tahap selanjutnya dilakukan pelaporan keuangan yang transparan dan akuntabel sebagai bagian dari pelatihan, sebagai aplikasi atas pelatihan yang dilakukan. 3) Hasil yang diharapkan. Sesudah pelaksanaan pelatihan disertai praktik sistem pengelolaan keuangan yang belum efisien dan efektif dan pelaporan keuangan yang transparan dan akuntabel, maka diharapkan akan terjadi perubahan perilaku. Tahapan ini dapat diuji melalui tahapan sekurangnya satu bulan sesudah pelatihan. Kerangka konseptual pemecahan masalah dapat dilihat melalui gambar proses berikut:

Gambar 1. Kerangka Konseptual Pemecahan Masalah

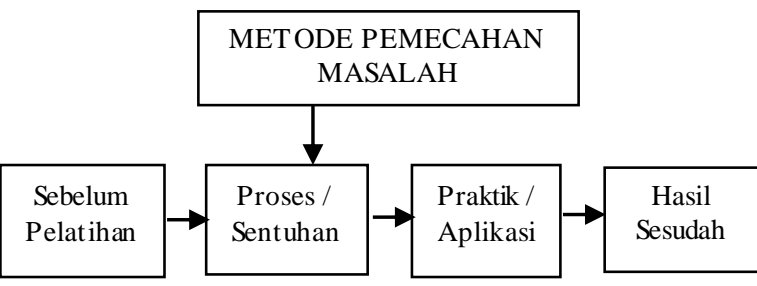

Untuk mengatasi permasalahan tersebut maka dapat dilakukan realisasi pemecahan masalah dilakukan di lapangan dengan caracara sebagai berikut:

1) Memberi pemahaman dalam bentuk penyuluhan mengenai kewirausahaan sebagai modal awal dalam mengembangkan usaha. Bentuk kegiatannya adalah pelatihan motivasi berusaha dan kewirausahaan, yang dilakukan dengan metode ceramah, tanya jawab, dan pemberian contoh.

2) Latihan mengembangkan usaha ekonomi produktif dalam bentuk Kelompok Usaha Bersama yang didasarkan pada potensi kelompok.

Kegiatan pelatihan dilakukan dengan metode ceramah, metode tanya jawab, dan metode demonstrasi, diakhiri dengan praktek lapangan. Metode ini digunakan untuk menyampaikan materi kegiatan, setelah materi disampaikan dilanjutkan dengan metode diskusi antara sesama peserta diklat.Metode diklat yang dimaksud adalah keseluruhan cara dan teknik penyampaian. Materi dalam proses belajar mengajar yang antara lain berbentuk: 1). Ceramah; 2). Diskusi; 3). Seminar; 4). Praktek; 5). Studi Kasus; 6). Simulasi.

Khalayak sasaran yang strategis dalam kegiatan ini adalah masyarakat Kelompok Usaha Kecil yang tergolong dalam Bentuk Warung, Rumah Makan Kecil (Kantin) yang berada di Desa Krondoran Kecamatan Langowan Timur Kabupaten Minahasa yang tersebar dalam tiga kelurahan. Jumlah peserta pelatihan direncanakan sebanyak duapuluh orang, namun ada tambahan sebanyak lima orang, sehingga menjadi duapuluh lima orang terdiri atas pria dan wanita, dengan rincian sebagai berikut: Pemilik warung sebanyak sepuluh Orang; Pemilik Rumah makan Kecil sebanyak tiga Orang; Pemilik Industri Kecil sebanyak tujuh Orang; dan Perangkat Desa/Tokoh Masyarakat sebanyak lima Orang.

Dalam rangka mencapai tujuan yang tercantum di atas, maka ditempuh langkahlangkah sebagai berikut:

1) Menghubungi Kepala Desa Karondoran dan Camat Langowan Timur untuk mendiskusikan topik yang hendak diabdikan yaitu pemberdayaan usaha ekonomi produktif bagi masyarakat miskin dan mencari data jumlah warga masyarakat yang tergolong pemilik usaha kecil sebagai calon peserta pelatihan.

2) Menyelenggarakan pelatihan.

3) Untuk menilai keberhasilan program kegiatan ini adalah : 
a) $80 \%$ peserta yang diundang hadir dalam pelatihan

b) Terlaksananya seluruh kegiatan pelatihan kewirausahaan

c) $40 \%$ peserta mampu mengembangkan usaha ekonomi produktif dengan pendampingan dari tim pengabdi

d) Pernyataan kepuasan dari peserta pelatihan, dan pemerintah setempat.

Evaluasi kegiatan dilaksanakan pada pra kegiatan (kegiatan awal), dalam bentuk pretes, selama berlangsungnya kegiatan (evaluasi proses), serta akhir kegiatan dengan maksud mengevaluasi penyerapan materi dalam bentuk postes dan ditambah kegiatan praktik yang dilakukan.Penilaian terhadap aspek penguasaan materi meliputi: ujian tertulis, ujian praktek, dan studi kasus/praktikum. Unsur dan bobot penilaian aspek penguasaan materi adalah sebagai berikut :

a) Ujian tertulis (bobot 40\%). Bentuk ujian tertulis bisa berupa pilihan ganda atau esai atau gabungan keduanya. Materi yang dicakup pada ujian ini ada seluruh teori yang diajarkan pada setiap mata diklat.

b) Ujian praktik (bobot 30\%). Bentuk ujian praktik berupa prakter bagaimana cara menyusun pembukuan dengan benar dan tepat.

c) Studi kasus (bobot 30\%). Studi kasus berupa peragaan/praktikum/presentasi tugas akhir yang diberikan selama diklat. Kegiatan ini dilaksanakan secara perorangan atau berkelompok dengan mencermati persoalan yang pernah dialamai selama mengelola keuangan sekolahnya dan berusaha memecahkan persoalan tersebut setelah mendapatkan materi maupun dengan bertanya kepada pemateri.

d) Kualifikasi keberhasilan peserta mengikuti ketentuan sebagai berikut :

- Sangat Memuaskan (skor : 95,0 100,0);

- Memuaskan (skor : 90,0 - 94,9);

- Baik Sekali (skor : 80,0 - 89,9);

- Baik (skor : 70,0 - 79,9);

- Tidak Berhasil (skor di bawah 70,0).

\section{HASIL DAN PEMBAHASAN}

Pelaksanaan kegiatan pengabdian kepada masyarakat tentang Pelatihan Tata Kelola Keuangan Bagi Kelompok Usaha Kecil Di Desa Karondoran Kecamatan Langowan Timur, diperoleh hasil kegiatan sebagai berikut: Pelaksanaan kegiatan dilaksanakan selama empat hari kerja, yakni setiap hari jumat dan sabtu, tanggal 5 dan 6 , serta tanggall3 dan 14 Mei 2016. Hari pertama, kedua, dan ketiga dilaksanakan dalam bentuk pemberian teori dengan metode ceramah bervariasi disertai dengan diskusi dan simulasi tata cara penyusunan pembukuan usaha kecil, sedangkan hari keempat dilaksanakan dalam bentuk praktik dan diskusi-diskusi serta melakukan evaluasi kegiatan dalam rangka penyempurnaan sistem pembukuan usaha kecil sampai pada penyusunan laporan rugi dan laba.

Sesuai dengan rencana kegiatan, maka diklat dilaksanakan dengan kegiatan pokok pelatihan tata kelola keuangan bagi kelompok usaha kecil di Desa Karondoran Kecamatan Langowan Timur, meliputi :

1. Ceramah, diskusi dan simulasi tentang : Manajemen Usaha dan Pengelolaan Keuangan Usaha Kecil, yang disajikan oleh : Dr. Johny Manaroinsong, M.Si. Materi ini bermaksud untuk memberikan pengetahuan dan pemahaman tentang cara-cara memanajemen usaha kecil yang dikelola, mulai dari merencanakan, mengorganisasikan usaha, melaksanakan, sampai pada melakukan evaluasi usaha yang dilakukan.

2. Ceramah, diskusi dan simulasi tentang : Akuntansi/Pembukuan Usaha Kecil, yang disajikan oleh : Linda Tanor, SE, M.SA, dosen yang mengajar pengantar akuntansi. Materi ini bermaksud untuk memberikan pemahaman tentang caracara melakukan pembukuan usaha kecil secara sistematis. Dilanjutkan dengan materi tentang: Teknik Menghitung Laba Rugi Usaha Kecil, yang disajikan oleh Dr. Johny Manaroinsong, M.Si, sebagai dosen pengajar pengantar akuntansi. Materi ini bermaksud untuk memberikan pemahaman cara-cara menghitung laba atau rugi kegiatan, sehingga mereka tahu dengan pasti apakah usahanya 
memperoleh laba atau rugi, sehingga dapat menyusun rencana strategis yang lebih menguntungkan berikutnya.

3. Ceramah, diskusi dan simulasi tentang : Teknik menyusun kelayakan usaha untuk permintan kredit UMK di Bank, yang disajikan oleh: Dr. Mareyke G.V. Sumual, M.Si, dan Dr. Lennij Henij Suoth, M.P, dosen yang mengajarkan studi kelayakan usaha. Materi ini bermaksud untuk memberikan pemahaman cara-cara menelaah apakah usaha yang akan dijankan menguntungkan atau tidak, serta kegiatan ini dapat dijadikan acuan jika ingin menambah modal usaha melalui bantuan kredit usaha kecil (KUK) dari pihak bank atau lembaga keuangan lainnya.

4. Praktik tentang :

- Sistem/prosedur pembukuan usaha kecil;

- Teknik menyusun dan menghitung laba rugi usaha;

- Teknik menyusun studi kelayakan usaha kecil untuk memperoleh modal usaha;

- Melaksanakan diskusi akhir berkaitan dengan system dan prosedur pembukuan usaha kecil, laba rugi, dan studi kelayakan usaha, serta melahirkan model yang diinginkan sesuai tujuan. Selanjutnya melakukan evalusi atas kegiatan peserta.

Seluruh kegiatan pengabdian yang dilakukan direspons positif oleh peserta yang terdiri atas unsur pemilik warung, pelaku usaha industri kecil, pemilik usaha rumah makan, serta tokoh masyarakat dan perangkat desa yang berkeinginan untuk ikut kegiatan yang ada di Desa Karondoran Kecamatan Langowan Timur. Peserta yang hadir selama pelaksanaan kegiatan ini sangat antusias mengikuti semua yang disampaikan dalam bentuk teori maupun praktik kegiatan. Hasil pengamatan selama pelaksanaan kegiatan yangn ditunjang dengan hasil evaluasi atas pelaksanaan kegiatan pelatihan terhadap khalayak sasaran atau peserta yakni pemilik warung, pelaku usaha industri kecil, pemilik usaha rumah makan, , serta tokoh masyarakat dan perangkat desa yang berkeinginan untuk ikut kegiatanyang ada di
Desa Karondoran Kecamatan Langowan Timur, diperoleh beberapa hasl pokok, antara lain bahwa peserta memiliki keinginan kuat untuk memperoleh baik secara teoritis maupun parktik hal-hal yang berhubungan dengan kegiatan-kegiatan yang sangat dibutuhkan itu. Kegiatan-kegiatan yang dilakukan memang sangat menunjang para pemilik usaha kecil serta pemerintah desa dalam pelatihan ini sehingga kedepan menjadi pengusaha-pengusaha sukses di desa sehingga usahanya menjadi lebih teratur dan selalu terencana dalam pelaksanaan kegiatan sesuai dengan yang diinginkan oleh pemerintah.

Walaupun beberapa diantara peserta yang hadir sibuk melakukan usahanya sehari-hari, namun antusiasme para peserta pelatihan sangat tinggi karena dari hasil evaluasi awal maupun proses, ternyata para khalayak sasaran banyak yang belum mengetahui materi maupun kegiatan yang berkaitan dengan prosedur pembukuan usaha kecil dan rencana kelayakan usaha (businness Plan)lebih khusus secara teoritis, serta teknik penyusunan pembukuan. Hampir semua materi dianggap sangat menarik bagi mereka, karena selain sangat diperlukan oleh pengusaha keciljuga dianggap baru bagi mereka, apalagi materinya disajikan langsung didiskusikan sehingga menarik bagi mereka.Responsif mereka dapat dilihat dari hasil kerja praktik dalam bentuk menghitung rugi labayang dibuat oleh mereka walaupun masih banyak yang masih perlu diperbaiki, namun bagi mereka ini adalah langkah awal untuk melakukkan perobahan mendasar di usaha mereka.

Oleh karena itu setelah dilakukan praktik terhadap materi tersebut, antusiasme peserta sangat tinggi. Ini ditunjukkan oleh banyak diantara para peserta berupaya menyusun dengan bantuan dan bimbingan penyaji dan pembimbing praktik dan setiap saat ingin bertanya tentang cara-cara mencatat transaksi usaha. Demikian juga halnya dengan praktik materi rencana kelayakan usaha (businness Plan), yang paling banyak bertanya adalah bagaimana menghitung rencana laba serta system pasar, system produk, serta strategi menetapkan harga jual yang pas tapi menguntungkan. Memang sangat disadari bahwa di desa yang 
mayoritas tingkat pendidikan yang kurang, menunjukkan bahwa kegiatan-kegiatan seperti ini jarang terjadi.Sementara itu mereka mengalami kesulitan dalam memahami cara-cara pembuatan dan pelaksanaan kegiatan. Untuk itulah kegiatan pelatihan yang berhubungan dengan materi tersebut merupakan kebutuhan yang tidak dapat ditawar-tawar, sehingga sangat direspons oleh para peserta sebagai pemilik usaha kecil dan pemerintah desa serta tokoh masyarakat desa.

Persoalan utama setelah kegiatan pelatihan ini selesai, yakni bantuan pendamping pada saat proses perubahan dari usaha-usaha tradisional ke usaha berorientasi modern, antara lain, sistem penyusunan berikut serta bagaimana mempraktikannya. Proses ini dilakukan dengan berkonsultasi melalui dinas terkait, seperti: pemerintah Kabupaten Minahsa atau perguruan tinggi yang memiliki kompeten membantu desa. Diharapkan pemerintah desa dan kecamatan maupun kabupaten akan dapat menjadi narasumber maupun mengarahkan mereka dalam menyusun studi keayakan bisnis yang lebih terarah dalam rangka memperoleh pinjaman KUK dari pihak Bank.

Implikasi atas temuan kegitan ini, sebagai berikut: 1) Kegiatan pelatihan ini merupakan langkah awal bagi para pengusaha kecil dan tokoh masyarakat desa, sehingga perlu adanya pemantauan dan bimbingan teknik secara khusus baik oleh instansi terkait, maupun pihak perguruan tinggi; dengan demikian kegiatan semacam ini sangat penting dilakukan oleh Lembaga Pengabdian Kepada Masyarakat Universitas Negeri Manado dalam melaksanakan tugas Tridharma Perguruan Tinggi. 2) Model dan siklus pembukuan usaha kecil, Contoh perhitungan rugi laba yang sederhana, serta Contoh studi kelayakan usaha (businness Plan) yang sederhana akan sangat membantu para pengusaha kecil dan tokoh masyarakat desa dalam melaksanakan tugas utama mereka. Oleh karena itu pelatihan dan pembiasaan para pengusaha kecil dan tokoh masyarakat desa secara terus menerus yang diikuti dengan perobahan-perobahan sesuai perkembangan usaha, akan sangat sangat dibutuhkan. Paling sedikit setahun sekali dilakukan pelatihan berkaitan dengan materi seperti yang dilatih sekarang ini wajib dilakukan. Oleh karena itu tanggung jawab pemerintah kabupaten maupun perguruan tinggi seperti Unima merupakan harapan pemerintah desa.

\section{KESIMPULAN}

Berdasarkan kajian atas kegiatan pengabdian yang dilakukan di Desa Karondoran Kecamatan Langowan Timur ini, maka berdasarkan hasil evaluasi, memperoleh hasil bahwa kegiatan ini sangat diperlukan oleh para pengusaha kecil termasuk pemerintah dan tokoh masyarakat desa setempat, karena memang sangat berkaitan dengan kebutuhan dan kewajiban pengelola usaha kecil. Atas dasar itu beberapa kesimpulan atas hasil kegiatan ini sebagai berikut:

1. Model dan siklus pembukuan usaha kecil merupakan materi penting yang bukan hanya diketahui, tapi patut dipahami dalam melakukan transaksi kegiatan usaha agar dapat dicatat dengan benar sesuai keadaan yang sebenarnya. Temuan yang diperoleh ternyata para pengusaha kecil lebih banyak menggunakan catatan-catatan umum yang dilakukan pada sebuah buku yang tidak sesuai dengan tatacara pembukuan. Para pengusaha kecil ini cenderung hanya mengutamakan catatan utang dan piutang, sedangkan transaksi dan rekening lainnya kurang dicatat, karena dianggap tidak diketahui.

2. Perhitungan rugi laba yang sederhana, juga merupakan materi penting yang wajib dipahami para pengusaha kecil di Desa Karondoran Kecamatan Langowan Timur. Hal ini penting, karena selama ini perhitungan rugi laba yang dibuat hanya dilakukan pada catatan-catatan kecil yang dibuat pada kertas yang tidak memadai, terutama pada warung-warung dan kantin, sehingga contoh perhitungan rugi-laba sangat dibutuhkan mereka.

3. Dari semua materi yang dilatih, ternyata materi "studi kelayakan usaha (businness Plan)"yang sederhana, merupakan matri yang sama sekali tidak diketahui apalagi dipamahi para pengusaha kecil yang dilatih. Sementara itu bagi pengusaha termasuk pengusaha kecil yang ingin 
melakukan perluasan usaha (expantion), wajib membuat prediksi tertulis untuk mengetahui apakah usaha yang direncanakan dapat menguntungkan ataukah tidak. Sementara para pengusaha kecil yang dilatih dalam melakukan perluasan usaha hanya menggunakan intuisi dan pengalaman untuk menentukan apakah usaha yang akan dilakukan menguntungkan ataukah tidak.

4. Sesuai hasil kegiatan pelatihan yang dilakukan kepadapara pengusaha kecil dan tokoh masyarakat yang ada di Desa Langowan Kecamatan Langowan Timur, sangat direspons positif karena sangat berkaitan dengan kegiatan mereka seharihari, sehingga dirasakan merupakan kebutuhan utama.

5. Setelah melaksanakan pengabdian kepada masyarakat dalam bentuk pelatihan, maka para pengusaha kecil yang ada di Desa Langowan Kecamatan Langowan Timur telah berhasil memperoleh pengetahuan tentang Model dan siklus pembukuan usaha kecil, Contoh perhitungan rugi laba yang sederhana, serta Contoh studi kelayakan usaha (businness Plan) yang sederhana, walaupun masih pada taraf yang sederhana. Namun telah dapat membuka wawasan mereka tentang pentingnya ketiga materi ini.

\section{REFERENSI}

Badan Pusat Statistik. 2013; Kendala utama UMKM berdasarkan sensus UMKM 2012. (Diunduh 14 Juni 2014); Tersedia Pada www.bps.go.id.

Kementrian Koperasi dan UKM. 2013;

Sektor UMKM Menyerap 97,3 persen Dari Total Tenaga Kerja Indonesia; [Diunduh 12 Juni 2014]; Tersedia pada: http://www.sindotrijaya.com/ news/detail/3910/sektor-umkmmenyerap-973-dari-total-tenaga-kerja indonesia\#. UrLo8OJWhds.

Subiyanto, Rachmad; 2013; UMKM: Keterbatasan Modal Jadi Kendala Pertumbuhan Usaha, bisnis.com, Balikpapan, Kalimatan Timur;
(Diunduh 14 Juni 2014). Tersedia Pada: http:// usahamodalkecil31.blogspot.co.id/201 2/08/kendala-usaha-kecil-menengahdan-solusi. html.

Ismawan B. 2013; Sebuah upaya perguruan tinggi mengatasi kemiskinan melalui pengembangan usaha mikro. Тети Nasional Penanggulangan Kemiskinan 2013 [Internet]; Depok (ID). hlm 1; [Diunduh 14 Juni 2014]. Tersedia Pada http://www.ui.ac.id/id/news/archive/68 83 